\title{
Decision making ability of agri- entrepreneurs at Jammu and Kathua districts of J \& K state, India
}

\author{
Bhavana Gupta ${ }^{1}$, Quadri Javeed Ahmad Peer $^{2}$ and Jaswinder Kaur ${ }^{3}$ \\ ${ }^{1}$ Division of Agricultural Extension Education, FOA, SKUAST-J, Chatha, INDIA \\ ${ }^{2}$ Division of Agricultural Extension Education, FOA,Wadura, SKUAST-Kashmir, INDIA \\ ${ }^{3}$ Department of Dry Land Agriculture, CCS HAU, Hisar (Haryana), INDIA \\ *Corresponding author. E-mail: qadrijavid2008@gmail.com
}

Received: August 5, 2014; Revised received: October 20, 2014; Accepted: December 3, 2014

\begin{abstract}
The concept of entrepreneurship has assumed prime importance in research and development for accelerating economic growth in developing countries. The Entrepreneurship development institution has been focusing its attention on developing programmes for entrepreneurship development and innovative training technique for trainers. The entrepreneurs are responsible for many economic decisions that rests on anticipating demand and bearing risks. The investigation on 210 agri-entrepreneurs thirty each from seven agri-enterprises namely vegetable growing, strawberry growing, dairy farming, mushroom growing, bee-keeping, poultry farming and flower growing, selected purposively from Jammu and Kathua districts of Jammu and Kashmir state revealed that one-half $(50.48 \%)$ of the agri-entrepreneurs were in the high category of decision making ability followed by medium $(46.19 \%)$ and low (3.33\%) levels. Majority (76.67\%) of vegetable entrepreneurs were in the high level of decision making ability followed by poultry entrepreneurs (56.67\%). Majority $(61.43 \%)$ of entrepreneurs had not received any training. Only $38.57 \%$ of entrepreneurs had received training. Bee-keepers were highest $(66.67 \%)$ who received training regarding their enterprise. Majority $(61.72 \%)$ of entrepreneurs received training for a period of seven days followed by $23.46 \%$ of entrepreneurs who got training for fifteen days and $14.81 \%$ who attended thirty days training. The study inferred that high level of decision making ability of agri- entrepreneurs might be due to individual ownership, high achievement motivation and high risk taking capacity. The appropriate decisions with regard to finalizing different technical, financial and marketing aspects at right time, results in the progress of the enterprise.
\end{abstract}

Keywords: Agri-entrepreneurship, Bee-keepers, Decision-making ability, Marketing

\section{INTRODUCTION}

India is a land of enterprises, where almost $70 \%$ of the population is still self-employed, and some place this estimate as high as 80\%. (Srilatha 2013). Entrepreneurship, a form of human behaviour, is indispensable for the growth and development of any society. Generally, the entrepreneur is considered as a person who initiates, organizes the activities, manages and controls the affairs of business unit combining the factors of production to supply goods and services. Farmers deciding to take particular crop or use scientific methods to grow crops also exhibit entrepreneurial behaviour (Palmurugan et al., 2008; Rao and De, 2009;). The economic development of a country is correlated with the population, employment, literacy and effective utilization process, which accelerates the growth including social change. To accelerate economic development, it is necessary to increase the supply of entrepreneurs. The economic development of a country is correlated with the population, employment, literacy and effective utilization process, which accelerates the growth including social change. To accelerate economic development, it is necessary to increase the supply of entrepreneurs. Entrepreneurs have to do conscious decision making with great deal of thought concerning starting of an enterprise, finalizing different products, expansion of enterprise, borrowing money, hiring workers and considering new ways of marketing. So, entrepreneurs have to make decisions under certain uncertainties. In order to know, whether entrepreneurs under such uncertain conditions take decisions at their own or they do in consultation with somebody else.

The findings will throw light on the various factors which motivates an entrepreneur to initiate, plan and organize the various enterprises. A number of social institutions, entrepreneurship development and financial institutes are mandated to help the entrepreneur in stimulating, sustaining and supporting their entrepreneurial endeavor. The entrepreneurs are to be updated with the technological innovations from time to time by imparting knowledge and skill based training. The needy people who cannot afford to arrange finance of their own are to be provided with 
financial help. The study will help in assessing the role of the technical and financial institutes in achieving the objectives they have been established for. It will reflect important entrepreneurial traits which can be replicated for the development of other entrepreneurs by providing necessary interventions. The investigation will also help to identify the various socio-economic, technical, and infrastructural constraints faced by the entrepreneurs. Findings of the study will suggest several research implications to the planners, policy makers, administrators to solve discrepancies, short-comings and missing links in achieving the targets. Keeping this in view, the decision making pattern was studied with the objective to study decision making capability of agri-entrepreneurs and the training attended by agri entrepreneurs.

\section{MATERIALS AND METHODS}

The study was conducted in two districts of Jammu and Kashmir namely, Jammu and Kathua. Seven enterprises which include dairy farming, poultry farming, bee-keeping, mushroom growing, flower growing, vegetable growing and strawberry growing were selected purposively as these enterprises were existing in the selected districts. From each of the identified farm based enterprise, except in strawberry and flower growers, 15 agri entrepreneurs each were selected purposively from districts of Jammu and Kathua respectively. In this way, 30 respondents each were selected purposively in respect of vegetable growing, mushroom, dairy, poultry and bee-keeping. As no strawberry entrepreneur was found in district Kathua, therefore, all 30 strawberry growers were selected from district Jammu. Similarly, 27 flower growers were selected from district Jammu and 3 from district Kathua due to non- availability of the flower growers in Kathua district, thus making a total of 210 entrepreneurs (Anonymous, 2010). The agri entrepreneurs were personally interviewed by framing a suitable pretested questionnaire. Based on scores obtained by the respondents, they were grouped into low medium and high category by adopting S.D. \pm Mean criteria for studying their decision making capability. As far as training attended by agri entrepreneurs is concerned, the findings were calculated in frequencies and percentages. The scale developed by Kapoor (1998) was used to measure decision making ability employed in the study. Finally respondents were catgorized on the basis of total scores as -Low = below (Mean-S.D), Medium $=$ inbetween $($ Mean \pm S.D $)$, High = above (Mean+S.D).

\section{RESULTS AND DISCUSSION}

Data registered in the Table 1 indicated that $10 \%$ of mushroom growers were in low category of decision making ability followed by $6.67 \%$ of flower growers and $3.33 \%$ of vegetable and dairy entrepreneurs each. None of the strawberry grower, poultry entrepreneur and bee-keeper was in low category of decision making ability. Similarly, it was observed that $66.6 \%$ of bee-keepers, $56.67 \%$ of dairy entrepreneurs, $50 \%$ of mushroom growers, $46.67 \%$ of strawberry growers, $43.33 \%$ of poultry entrepreneurs, $40 \%$ of flower growers and $20 \%$ of vegetable growers had medium category of decision making ability.Further, $76.67 \%$ of vegetable growers were in high category of decision making ability followed by poultry entrepreneurs $(56.67 \%)$, strawberry and flower growers $(53.33 \%)$ each, dairy entrepreneurs and mushroom growers (40\%) each and bee-keepers $(33.33 \%)$.

It is clear from the Table. 1 that overall $50.48 \%$ of respondents were in high category of decision making ability, $46.19 \%$ of respondents in medium category and $3.33 \%$ of respondents in low category of decision making ability.The high level of decision making ability of agri- entrepreneurs might be due to individual ownership, high achievement motivation and high risk taking capacity. The appropriate decisions with regard to finalizing different technical, financial and marketing aspects at right time, results in the progress of the enterprise. The above findings are in line with the findings of Solanki and Soni (2004) who reported that decision making ability of potato growers was largely at medium level $(65.56 \%)$ and Singh and Prasad (2007) revealed that in the process of decision making behaviour in agriculture, cent $\%$ of the farm women belonged to medium category. Kiran et al. (2012) indicated that the maximum respondents $(57 \%)$ had medium level of farm decision making followed by $28 \%$ had low and $15 \%$ had high level of farm decision making.

Training is an important component for upgrading the knowledge and skills of entrepreneurs. This component was studied in two aspects namely, training received and duration of training

Table 2 showed that as far as training received by the respondents was concerned, $66.67 \%$ of bee-keepers received training followed by poultry entrepreneurs $(60 \%)$, mushroom growers $(56.67 \%)$, dairy entrepreneurs $(33.33 \%)$, strawberry growers $(26.67 \%)$, flower growers $(23.33 \%)$ and vegetable growers (3.33\%). Similarly, $96.67 \%$ of vegetable growers had not received any training followed by flower growers (76.67\%), strawberry growers $(73.33 \%)$, dairy entrepreneurs $(66.67 \%)$, mushroom growers $(43.33 \%)$, poultry entrepreneurs $(40.00 \%)$ and bee-keepers $(33.33 \%)$.

Table 3 showed that cent $\%$ of vegetable and strawberry growers had received training of 1 week followed by poultry entrepreneurs $(77.78 \%)$, flower growers $(71.43 \%)$, mushroom growers $(64.70 \%)$, dairy entrepreneurs (50\%) and bee-keepers (30\%). Similarly, 50 per cent of bee-keepers received 15 days training followed by mushroom growers (29.41\%), flower growers $(28.57 \%)$ and poultry entrepreneurs $(11.11 \%)$. None of the vegetable grower, strawberry grower and dairy entrepreneurs had attended the training for 15 
Table 1. Distribution of entrepreneurs as per their decision making ability $(\mathrm{n}=210)$.

\begin{tabular}{lcccccccc}
\hline Category & $\begin{array}{c}\text { Vegetable } \\
\text { growers }\end{array}$ & $\begin{array}{c}\text { Strawberry } \\
\text { growers }\end{array}$ & $\begin{array}{c}\text { Dairy } \\
\text { entrepreneur }\end{array}$ & $\begin{array}{c}\text { Mushroom } \\
\text { growers }\end{array}$ & $\begin{array}{c}\text { Poultry } \\
\text { entrepreneurs }\end{array}$ & $\begin{array}{c}\text { Bee } \\
\text { keepers }\end{array}$ & $\begin{array}{c}\text { Flower } \\
\text { growers }\end{array}$ & Total \\
\hline Low & 1 & 0 & 1 & 3 & 0 & 0 & 2 & 7 \\
Score & $(3.33)$ & $(0.00)$ & $(3.33)$ & $(10.00)$ & $(0.00)$ & $(0.00)$ & $(6.67)$ & $(3.33)$ \\
& $<4$ & $<4$ & $<4$ & $<4$ & $<4$ & $<4$ & $<2$ & \\
Medium & 6 & 14 & 17 & 15 & 13 & 20 & 12 & 97 \\
Score & $(20.00)$ & $(46.67)$ & $(56.67)$ & $(50.00)$ & $(43.33)$ & $(66.67)$ & $(40.00)$ & $(46.19)$ \\
& $4-5$ & $4-5$ & $4-5$ & $4-5$ & $4-5$ & $4-5$ & $3-5$ & 16 \\
High & 23 & 16 & 12 & 12 & 17 & 10 & 16 & 106 \\
Score & $(76.67)$ & $(53.33)$ & $(40.00)$ & $(40.00)$ & $(56.67)$ & $(33.33)$ & $(53.33)$ & $(50.48)$ \\
& $>5$ & $>5$ & $>5$ & $>5$ & $>5$ & $>5$ & $>5$ & \\
Total & 30 & 30 & 30 & 30 & 30 & 30 & 30 & 210 \\
\hline
\end{tabular}

Figures in parentheses show percentages

Table 2. Distribution of entrepreneurs as per the trainings received $(n=210)$.

\begin{tabular}{lccc}
\hline Entrepreneurs & Training received & Not received & Total \\
\hline Vegetable growers & $1(3.33)$ & $29(96.67)$ & 30 \\
Strawberry growers & $8(26.67)$ & $22(73.33)$ & 30 \\
Dairy entrepreneurs & $10(33.33)$ & $20(66.67)$ & 30 \\
Mushroom growers & $17(56.67)$ & $13(43.33)$ & 30 \\
Poultry entrepreneurs & $18(60.00)$ & $12(40.00)$ & 30 \\
Bee keepers & $20(66.67)$ & $10(33.33)$ & 30 \\
Flower growers & $7(23.33)$ & $23(76.67)$ & 30 \\
Total & $81(38.57)$ & $129(61.43)$ & 210 \\
\hline
\end{tabular}

Figures in parentheses show percentages.

Table 3. Distribution of respondents as per the duration of training attended $(n=210)$.

\begin{tabular}{lcccc}
\hline Entrepreneurs & Training & \multicolumn{3}{c}{ Duration of training } \\
\cline { 3 - 5 } & attended & 1 week & 15 days & 30 days \\
\hline Vegetable growers & 1 & $1(100.00)$ & $0(0.00)$ & $0(0.00)$ \\
Strawberry growers & 8 & $8(100.00)$ & $0(0.00)$ & $0(0.00)$ \\
Dairy entrepreneurs & 10 & $5(50.00)$ & $0(0.00)$ & $5(50.00)$ \\
Mushroom growers & 17 & $11(64.70)$ & $5(29.41)$ & $1(5.89)$ \\
Poultry entrepreneurs & 18 & $14(77.78)$ & $2(11.11)$ & $2(11.11)$ \\
Bee keepers & 20 & $6(30.00)$ & $10(50.00)$ & $4(13.33)$ \\
Flower growers & 7 & $5(71.43)$ & $2(28.57)$ & $0(0.00)$ \\
\hline Total & $\mathbf{8 1}$ & $\mathbf{5 0}(\mathbf{6 1 . 7 2})$ & $\mathbf{1 9}(\mathbf{2 3 . 4 6})$ & $\mathbf{1 2}(\mathbf{1 4 . 8 1})$ \\
\hline
\end{tabular}

Figures in parentheses show percentages

days. One half $(50 \%)$ of dairy entrepreneurs received the training for a period of 30 days which was followed by bee-keepers $(13.33 \%)$, poultry entrepreneurs $(11.11 \%)$ and mushroom growers $(5.89 \%)$. Vegetable growers, strawberry growers and flower growers did not receive any training for a period of 30 days. A further look at the table showed that $61.72 \%$ respondents received training for 7 days which was followed by $23.46 \%$ and $14.81 \%$ respondents who received training for 15 days and 30 days respectively.

The highest percentage of training received by bee-keepers followed by poultry entrepreneurs might be due to the fact that dealing with the honey bees is a sensitive and skillful process. The owner should have knowledge of components like queen, drone, worker, apiary setting, colony inspection, management of bees and seasonal management. Extraction of honey is an art, different products are obtained from the colonies and needs technical know-how. Since poultry production is also risky enterprise as the chick mortality is high due to environmental conditions and diseases, majority of the poultry entrepreneurs had attended one week training which might have helped them in operating their units efficiently. Minute number of vegetable 
growers had received training in vegetable growing. The probable reason might be that vegetable growing is an age old practice and only traditional vegetables like radish, knol-khol, cauliflower, okra, tomato were grown and no new crop or technology might be available in which the growers could be trained.. The data revealed that the institutions which are concerned with capacity building of different entrepreneurs had not fulfilled their job of providing sufficient training to the respondents. These findings are similar with the findings of Bhagat (1992) who revealed that all the respondents appeared favorable about the training programme with responses 'very useful' (80\%) and 'useful' (20\%). They felt that the training was of right duration. All the inputs of training were substantially accepted in terms of their relevance, coverage and presentation. Kapoor (1998) revealed that in case of rural women entrepreneurs, $44 \%$ got training in bee-keeping and $8 \%$ in rabbit farming and only $4 \%$ in mushroom growing. The another $44 \%$ got no training at all. In urban women entrepreneurs, $38 \%$ got training in entrepreneurial development programme and $6 \%$ got no training. Firdoos (2001) observed that majority $(53.40 \%)$ of bee-keepers, vegetable growers and dairy entrepreneurs had not received any training while $46.60 \%$ received training related to the enterprise. Nath et al. (2001) found that majority of the opinion leaders received information by training on farm $(90 \%)$ followed by the Agricultural Extension Officers $(86.66 \%)$, field day $(80 \%)$ and result demonsration $(76.66 \%)$, under the personal cosmopolite sources. Training on station $(90.99 \%)$, training on farm $(83.33 \%)$ and field day $(70 \%)$ were the personal

cosmopolite sources perceived in order of importance by concerned farmers and Khajuria et al. (2001) reported that among personal cosmopolite channels, demonstration (MS 1.38), group meetings (MS 1.36) and training (MS 0.95) were utilized to a greater extent by the farmers.

\section{Conclusion}

The study revealed that one-half of agri- entrepreneurs had high level of decision making ability followed by medium and low levels. Majority of vegetable entrepreneurs were in high level of decision making ability followed by poultry entrepreneurs .Majority of agri- entrepreneurs had not received any training. Among them bee-keepers were highest who received training regarding their enterprise. Majority of agri-entrepreneurs attended training for a period of seven days followed by agri-entrepreneurs who got training for fifteen days and thirty days respectively. So, it is important that their entrepreneurial skills are recognized and facilities for training are created so that agri-entrepreneurs become technically sound and enjoy the benefits of independence and flexibility in their work lives.

\section{REFERENCES}

Anonymous (2010). A note on command area development Department of Agriculture, Jammu.

Bhagat, G.R. (1992). Developing and testing entrepreneurship development training capsule for farmers. Ph.D. thesis, Indian Agricultural Research Institute, New Delhi, India.

Srilatha. Ch, Vani. (2013).Constraints in management of dairy micro enterprises faced by women entrepreneurs of Andhra Pradesh, A. Indian Res. J. Ext. Edu. 13 (3): 106-108

Firdoos, R. (2001). Determinants of entrepreneurship among members of Punjab Kissan Club of Punjab Agricultural University, Ludhiana. M.Sc. thesis, Punjab Agricultural University, Ludhiana, India.

Kapoor, K. (1998). Entrepreneurial behaviour: A study of selected women entrepreneurs. M.Sc. thesis, Punjab Agricultural University, Ludhiana, India.

Khajuria, R., Sharma, F.L. and Podikunju, B. (2001). Opinion of farmers towards sprinkler irrigation technology in Udaipur district of Rajasthan. Rajasthan Journal of Extension Education. 8 \& 9: 48-52.

Kiran, Dipak, De., Gupta, B.K. and Pandey, D.K. (2012).Entrepreneurial behaviour in rural women of Sultanpur district of Uttar Pradesh, Indian Res. J. Ext. Edu.12(2): 29-33.

Nath, A., Rao, G.G., Babu, V.R. and Girdhar, I.K. (2001). Communication behaviour of opinion leaders in saline black soils of Gujarat. Indian Journal of Extension Education. 37(1\&2): 77-80.

Palmurugan, M, Jhamtani, A. and Padaria, R.N. (2008). Entrepreneurial behaviour of vanilla growers of Tamil Nadu and Kerala, Indian J. of Ext. Edu., 44 (1 \& 2): 5865 .

Rao, M.S. and De. D.(2009). Dimensions of Entrepreneurial behaviour, Indian J. of Ext. Edu., 45 (1 \& 2):16-20.

Singh, N.N. and Prasad, A. (2007). Decision making by farm women in Manipur - A case study. Agricultural Extension Review. 15: 41-46.

Solanki, K.D. and Soni, M.C. (2004). Entrepreneurial beha iour of potato growers. Indian Journal of Extension Education. 40: 33-36. 